\title{
Ancient plant DNA in archaeobotany
}

\author{
Angela Schlumbaum • Marrie Tensen · \\ Viviane Jaenicke-Després
}

Received: 20 December 2006/Accepted: 10 June 2007/Published online: 10 August 2007

(C) Springer Verlag 2007

\begin{abstract}
Plant diaspores, tissues and wood are preserved in natural and anthropogenic sediments. Also, over the past centuries, plants have been collected in herbaria. These plant remains carry macroscopic and molecular information, making them a rich source for reconstructing past plant use, agriculture, diet or vegetation-they are thus proxies for past economies, ecology, migrations or trade. This article focuses on the application of ancient DNA analyses from plants excavated at Holocene archaeological sites. A short methodological section is added to illustrate possibilities and limitations of ancient DNA research in plants.
\end{abstract}

Keywords Plant macroremains - Ancient DNA . Cereals $\cdot$ Fruit $\cdot$ Wood $\cdot$ Genetics

\section{Introduction}

After death DNA is degraded by various biotic and abiotic processes, resulting in fragmentation and modification of original sequence information. The very details of the

Communicated by F. Bittmann.

\footnotetext{
A. Schlumbaum ( $\square)$

Institute of Prehistory and Archaeological Science,

University of Basel, Spalenring 145,

4055 Basel, Switzerland

e-mail: angela.schlumbaum@unibas.ch

M. Tensen

Dukaat 78, 8253 BR Dronten, The Netherlands

V. Jaenicke-Després

Department of Biogeochemistry,

Max Planck Institute for Chemistry,

J.-J.-Becherweg 2, 55128 Mainz, Germany
}

whole process of DNA preservation and the mode of modifications at sequence level are still subject to research (Gilbert et al. 2003, 2007a; Pääbo et al. 2004; Hansen et al. 2006; Stiller et al. 2006). It has emerged however, that cold, dry and/or low oxygen environments are beneficial for DNA survival; for this reason, freshly excavated material is best stored cold or frozen (Burger et al. 1999; Smith et al. 2001; Pruvost et al. 2007). These DNA fragments still contain information which may help us to understand agricultural or vegetation history.

Archaeobotanists reconstruct the past by morphological analysis of all types of plant remains. Interpretation of botanical remains through morphological evidence has many advantages: the analysis is comparatively quick, technically simple and extensive reference collections are available to help interpretation. It does, however, also have some limitations. In the cases discussed below, substantial new information may be gained from ancient DNA (aDNA) research.

1. Archaeobotanical reconstructions depend on the level of identification of plant species and on their chance of being preserved in the archaeological record (Jacomet and Kreuz 1999). In the archaeological record, plant remains are preserved charred, waterlogged, desiccated or mineralized, depending on geography or on the context excavated. The chances of a plant species being detected and morphologically identified to a certain taxonomical level are strongly influenced by the type of preservation and by the plant's morphology. Thus, both have a major impact on any conclusions to be drawn. In cereals, examples of ambiguity in morphological features, even at ploidy level, are the grains of so-called naked wheat common in the Neolithic (Jacomet and Schlichtherle 1984; 
Maier 1996; Zohary and Hopf 2000) or the "new glume wheat" found so far at Neolithic and Bronze Age sites (Jones et al. 2000; Kohler-Schneider 2003). The latter might be an extinct wheat cultivar or evenas suggested by aDNA-a wheat related to Triticum timopheevii with the $\mathrm{G}$ genome (Brown et al. 1998). Other types of remains, such as tubers, tissue or fibres, are also inherently morphologically not very distinctive. In all cases, DNA can help to shed light on species diversity during different cultural periods by typing species-specific genomic regions.

2. In all but a few cases, it is unclear whether observed morphological diversity of diaspores can be ascribed to the location of the seed in the flower, to preservation conditions, to being the result of environmental conditions, or whether such differences in morphology are related to genetic diversity which could then point to the presence of landraces of crops. Charred wheat grains are good examples of diverse morphological forms within one taxon (Jacomet et al. 1989). aDNA research can clarify such cases by investigation of genetic diversity within samples of a species from a defined context.

3. The evaluation of the importance of trade versus local agricultural diversity is complicated because it is difficult to establish whether cultivated plants were grown locally, or if they were imported from other regions. This point is particularly interesting at cultural transitions, when new edible plants appear. Examples are the many fruit species found north of the Alps in Roman times. aDNA can help to identify the origin of ancient plant remains through analysis of alleles or haplotypes known to have a geographically structured distribution in a taxon.

4. Understanding the process of domestication is still an important issue in archaeology (e.g. Zeder 2006; Zeder et al. 2006). Some traits of domestication are morphologically visible, such as the brittle rachis in cereals, but many are not. It remains unclear in which order and at which time points these traits were selected, unless they left a visible signature on well-dated archaeological remains. When the genes that have been selected during domestication have been identified, they can be studied in ancient plant remains and help the understanding in more detail of how domestication occurred. Through this analysis information can also be gained on the spread of domesticates and the status of selection of a plant at the onset of its spread. This is also true for the detection of selection for the dietary or medicinal values of plants, which can be studied through the genes important for metabolic pathways or economic traits in archaeological plant remains.
Although modern genetic studies have made major contributions to our understanding of, for example, modes of domestication, migrations or biogeography (e.g. ArroyoGarcia et al. 2006; Luo et al. 2007; Morrel and Clegg 2007), the value of ancient plant DNA studies is clear. Firstly, they allow the detection in situ and at a precise time of earlier temporal and spatial occurrences of species and their biodiversity, their migration and the routes involved. This is also valuable in respect of preserving lost genetic diversity information (Hodkinson et al. 2007). Secondly, they can provide the confirmation or rejection of models from modern DNA studies. Thirdly, aDNA is our only source of information in cases where wild ancestors or ancient cultivars are extinct. Fourthly, they are independent of recent cultural impact, and finally, aDNA studies enable us to test historical written sources (e.g. Vouillamoz et al. 2006).

\section{Potential of plant ancient DNA-studies of plant ancient DNA}

Most publications on plant aDNA in relation to archaeology focus on cultivated plants (see reviews Brown et al. 1993; Brown and Brown 1994; Jones et al. 1996; Brown 1999; Jones and Brown 2000). A few focus on wild plants, such as forest trees (see reviews Parducci and Petit 2004; Gugerli et al. 2005; Bennett and Parducci 2006). Regrettably, archaeological plant remains have attracted less attention from aDNA researchers than animal or human remains. And, just as in animal and human aDNA research, so far topics have often only been investigated briefly, studies rarely being followed up or satisfactorily completed.

In the following section, we give an overview of research that has been carried out on ancient plants, without discussing the reliablity of the individual papers (see "Verification in plant ancient DNA research"). This is because even with all the criteria of authenticity fulfilled (Cooper and Poinar 2000), the authenticity of aDNA can never be fully guaranteed (Gilbert et al. 2005). In general, one can say that the earlier studies in the field used less stringent methods and arguments for authentication of aDNA results, while in the more recent studies, the lessons on contamination prevention and authentication learnt since then have been incorporated. Both aspects (prevention of contamination and authentication of results) must be kept in mind when judging the literature on aDNA.

Cultivated plants—cereals and fruits

At European archaeological sites cereals are mainly preserved in a charred condition. Grains and chaff 
predominate, ears are rare. Any study of the history of cereal crops in Europe and the Near East would have to to be based on charred material. One of the economically important traits of wheat is the visco-elastic property of wheat dough, which is influenced by wheat storage proteins. These are highly variable, and certain glutenin alleles, e.g. those situated on the D-genome of wheat, have better bread-making qualities than others (Payne 1987). Hexaploid wheat such as Triticum aestivum is used today for bread-making, whereas tetraploid T. durum is used for making pasta. In the case of morphologically ambiguous wheat grains (Triticum species), genetic identification of wheat genomes by amplification of a genome-specific partial promoter region of the high molecular weight (HMW) glutenin subunit genes has aided in species designation by identification of ploidy level (Allaby et al. 1994; Brown et al. 1998; Schlumbaum et al. 1998; Allaby et al. 1999). Thus, for example, the presence of hexaploid wheat was established at one of the Neolithic lakeshore settlements in Switzerland (Schlumbaum et al. 1998).

In certain regions, crop plants may survive through desiccation in deserts or in caves. Investigations of DNA from plant remains from archaeological sites in Egypt have been reported for radish (O'Donoghue et al. 1996), sorghum (Deakin et al. 1998a, b) and papyri (Marota et al. 2002). In the case of maize (Zea mays), its origin, its domestication and impact on diversity, and its subsequent spread over the American continent form one central topic in molecular genetic and archaeobotanical research (Benz 2001; Piperno and Flannery 2001; Doebley 2004). The first attempt to shed light on maize diversity used analysis of transposable elements $(M u)$ in pre-Columbian maize kernels (Rollo et al. 1994). The manner in which domesticated maize spread into and within South America was inferred from DNA analyses of allelic diversity in the alcohol dehydrogenase $(a d h)$ gene and of microsatellite loci in modern landraces and in desiccated maize cobs excavated in caves (Freitas et al. 2003; Lia et al. 2007).

A genetic comparison of modern domesticated plants with their ancestors opens up the possibility of identifying traits which have been selected during domestication. In maize, such genes have been identified and are characterized by reduced diversity in maize landraces and inbred maize in comparison to their wild ancestor teosinte (Wang et al. 1999; Vigouroux et al. 2002; Whitt et al. 2002; Wang et al. 2005). The analysis in ancient maize remains of short fragments within these genes makes it possible to investigate approximately when the alleles common in modern maize were selected, and at which time other alleles which are only known from teosinte were still present in the population. So far, three such selected genes have been studied in maize cobs preserved through desiccation. These genes affect not only plant morphology but also the quantity and quality of starch and proteins in ancient maize and were found to be already selected 4,400 years ago (Jaenicke-Després et al. 2003).

Ancient DNA investigations relating to the domestication of rice are summarised in Jones and Brown (2000).

Recently first attempts were made to understand the beginnings of horticulture in Europe. The growing of grapes (Vitis vinifera) and production of wine is a good example of the study of regional traditions versus the influence of "foreign" cultures. V. vinifera is propagated vegetatively, probably since ancient times. Surprisingly little genetic homogenization took place despite large cultivar diversity and intensive breeding of new cultivars, since microsatellite variability in modern cultivars is known to be structured geographically and at cultivar level (Sefc et al. 2000; Aradhya et al. 2003; This et al. 2004). This permits speculation about the origin of historically known cultivars (Vouillamoz et al. 2006) and comparison with ancient cultivars. Microsatellite loci have been used to investigate the origins of $V$. vinifera seeds preserved by waterlogging and charring at several European Celtic, Greek and Roman sites. At all sites there was evidence of wine production. Amplification of as few as two or three microsatellite loci already permitted tentative assignments of the origins of the wine plant in a defined archaeological context (Manen et al. 2003).

Another exciting opportunity is the use of geographically distributed genetic markers discovered in modern wild or domestic species. This approach has been successfully used to trace the introduction of bottle gourd (Lagenaria siceraria) into the Americas from Asia as early as cal. 8900 B.P. (Erickson et al. 2005) by studying single nucleotide polymorphisms (SNPs) in chloroplast trn intergenic spacer regions.

Some studies have hinted at the potential for gaining information using aDNA by demonstrating the feasibility of future studies in waterlogged plant remains with a woody exocarp. For example in the Northern Alpine region, the beginning of fruit-growing coincided with the Roman occupation (Jacomet and Mermod 2002) and formed the start of an agricultural development that still leaves its mark on the regional agriculture today. At the archaeological sites in this region, fruit-stones of Prunus domestica, $P$. insititia, $P$. persica and other species are abundant and preserved mainly by waterlogging. In a first study of morphologically ambiguous Prunus fruit stones which were either wild $P$. spinosa or cultivated $P$. insititia, the maternal parent was identified as wild sloe (Pollmann et al. 2005). One advantage of Prunus fruit stones for aDNA studies is that they are large enough for separate analysis of maternal tissues, and for replicated results from the same individual stone. Another example is the successful DNA analysis of waterlogged olive fruit stones 
(Elbaum et al. 2005), which opens up the possibility for understanding the complex domestication history of this species.

Although it is not the focus of this review, useful information can also be gained from herbarium specimens and other desiccated medieval or historical plant materials. Landraces, which are available from seed banks and go back to the early twentieth century, although much younger than archaeological samples, pre-date the industrial revolution and large-scale modern breeding efforts. They thus provide meaningful information on the status quo ante and on plant phylogeny. Very interestingly, they also provide information on the presence and evolution of plant pathogens, which of course have had a major impact on agricultural societies (Rogers and Bendich 1985; Bruns et al. 1990; Rogers 1994; Taylor and Swann 1994; Savolainen et al. 1995; Ristaino et al. 2001; Blatter et al. 2002b; Ristaino 2002).

\section{Vegetation and diet}

In archaeobotany, changes in vegetation are studied by investigating pollen from sediment cores-so far only few researchers have made use of this type of plant remains. Coniferous pollen from sediment cores was reported to contain DNA (Suyama et al. 2003; Parducci et al. 2005). Reconstruction of temporal vegetation changes was attempted from faeces (Hofreiter et al. 2003) and the potential of genetic analysis of frozen sediments for the reconstruction of past vegetation over thousands of years in correlation to climate changes was demonstrated (Willerslev et al. 2003). For these types of study vertical migration of DNA must be controlled (Haile et al. 2007)

The analysis of aDNA from trees (Liepelt et al. 2006) opens up not only the possibility of investigating the evolution of genetic diversity in tree populations through time (Tani et al. 2003) but also of reconstructing the geographic origin of timber used at a particular site. Thus it proved possible to establish the regional provenance of oaks used in constructions at several European sites (DumolinLapègue et al. 1999; Deguilloux et al. 2003).

aDNA analyses of complex plant mixtures, as found for example in faeces (Poinar et al. 1998; Hofreiter et al. 2000; Poinar et al. 2001; Kuch et al. 2002; Hofreiter et al. 2003; Iniguez et al. 2003), demonstrate the potential of aDNA studies and of collaboration between geneticists and morphologists for the reconstruction of diet. Even more information has been gained from faeces by employing both types of investigation. Apart from faeces, gut contents have been used to reconstruct diet genetically (Rollo et al. 2002).

\section{Methodological aspects of plant ancient DNA}

Plant genomes

Plants have three genomic compartments: nucleus, mitochondria and chloroplasts, each differing in mutation rates and with complex modes of inheritance. Plants can be diploid, but also polyploid or can have genome duplications. They reproduce sexually and multiply vegetatively. Different species can hybridize. Propagation involves inbreeding or outcrossing, and plant spatial dispersal is mediated through different vectors such as wind, insects, birds or mammals - all of which influences the gene flow. All these plant-specific features have to be taken into account in plant aDNA studies.

\section{Methods}

In brief, the procedure for aDNA analysis in plants is as follows: excavation, morphological description, external cleaning if possible, powdering, DNA extraction, amplification of chosen target region within the plant's genome(s) by polymerase chain reaction (PCR), gel electrophoresis to establish presence of correct product size, cloning and sequencing, and verification.

Ideally, samples are taken directly at the excavation, taking care to prevent contamination from the environment (see "Verification in plant ancient DNA research"; Yang and Watt 2005). Detailed morphological documentation is needed as DNA investigations are destructive. Samples should be then stored cold or frozen to slow further DNA degradation (Burger et al. 1999; Poinar 2002; Pruvost et al. 2007). In the case of large, robust plant remains such as fruit stones external decontamination with bleach or UV light can be done before DNA analysis. Plant material is powdered by a Retch mill, mortar and pestle or other destructive methods. If possible, several hundred milligrams should be processed from ten individuals or more, to establish initial DNA preservation, followed ideally by analysis of individual specimens.

At present, there are no preferred extraction methods for ancient plant material, nor is there any comprehensive comparison of protocols, such as exists for animals (Rohland and Hofreiter 2007). CTAB/DTAB methods, silica-based methods or DNA extraction kits are employed (Allaby et al. 1997; Schlumbaum et al. 1998; DumolinLapègue et al. 1999; Blatter et al. 2002b; Jaenicke-Després et al. 2003; Manen et al. 2003; Pollmann et al. 2005; Liepelt et al. 2006). These methods for DNA extraction were developed taking into account that plant parts are rich in secondary byproducts, sugars and other potential inhibitors of PCR. Modifications, such as the use of PTB 
( $N$-phenacylthiazolium bromide), are suggested in cases where Maillard products are expected (Poinar 2002). However, in animal studies, PTB and other additives have been shown to be neither advantageous nor disadvantageous (Rohland and Hofreiter 2007). Dilution of extracts or an increase of the amount of Taq polymerase is often sufficient to overcome PCR inhibition. For genetic analysis, universal or specific plant genome target sequences are chosen, depending on the goal of the project (see "Examples of markers used in ancient DNA studies"). So far, in aDNA studies targets have been amplified in single PCRs, cloned and sequenced.

Sequencing after cloning is still the method of choice, to account for modifications due either to polymerase errors or DNA post-mortem damage (Bower et al. 2005; Ho et al. 2007). Mosaic sequences as a result of jumping PCR (Pääbo et al. 1990) between either different genomes of a polyploid (Allaby et al. 1999) or between nuclear genes with multiple copies such as ribosomal DNA, or PCR slippage in the case of microsatellites, have to be identified and eliminated by sequencing cloned PCR products. Multiplex PCR, that is the simultaneous amplification of several target regions, has so far not been realised in plant aDNA. Generally, target regions between 90 and 300 bp (base pair) are amplified. Quantitative realtime PCR may be used to establish the amount of target sequences preserved, but, due to the degradation process, we doubt that real-time PCR is useful, for example, for identification of ploidy levels in archaeological remains. In contrast, pyrosequencing (Ronaghi 2001; Margulies et al. 2005), employed in whole genome sequencing of modern organisms, though still very expensive, could be useful in ancient plant genetics in the future (e.g. for ploidy identification) as it does not rely on PCR amplification.

Other methods that are common in modern molecular plant biology, in particular those employed to study populations or genetic diversity such as RAPD or AFLP and related methods, are problematic with archaeological plant remains, because templates are damaged and degraded. This aDNA damage results in absent bands (=allelic dropouts) or in artificial bands, produced by the presence of co-extracted contaminating modern or archaeological plant material or by polyploidy or gene duplication. Nevertheless, some reports have been published (Siles et al. 2000; Suh et al. 2000; Iniguez et al. 2003; Gyulai et al. 2006).

In principle, knowledge of DNA sequences in living plants is required for aDNA studies. Such sequence information can be found in public databases such as GenBank/ EMBL (http://www.ncbi.nlm.nih.gov/entrez/query.fcgi). Unfortunately, some plants, especially those of European origin, are clearly underrepresented in these databases.
Verification in plant ancient DNA research

Most plants have small seeds. As a consequence, most archaeological plant remains are small. Wood, large stonefruits or complete cereal ears are exceptions to this rule. This smallness of plant remains has consequences both for the proof of authenticity, as required in aDNA studies, and for work at the individual level.

Criteria of authenticity were first published in relation to human remains (Cooper and Poinar 2000; Hummel 2003), and were only later suggested in the context of plant aDNA (Parducci and Petit 2004). They involve several different strategies (such as strict separation of pre- and post-PCR areas, an inverse relationship between amplification success and target length, reproducibility, and preferential amplification of plastid DNA over single copy nuclear DNA, although exceptions to this rule were reported: Banerjee and Brown 2002; Gilbert et al. 2007b) and ultimately acknowledge a sort of "common sense" to ensure the ancient origin of the DNA sequences found (Pääbo et al. 2004; Gilbert et al. 2005). In plant aDNA research, ensuring the authenticity of the sequences and the exclusion of contaminants is comparable to the problem of excluding modern human DNA in human aDNA work, but it can be easier to achieve, for example by using speciesspecific primers in cases of morphologically identified plant taxa.

Contamination of archaeological plant remains can come from different sources. Vast quantities of pollen from modern plants are present in the air. In the soil seeds and roots can come into contact with the ancient specimen. Also during identification using modern reference specimens, contamination with modern DNA can occur and in principle, archaeological plant remains can contaminate each other, for example in storage assemblages. Pollen is even smaller than seeds. Cross-contamination with modern pollen, for example during periods of pollen dispersal of outbreeding species such as Pinus is very possible, both during excavation or later stages of preparation. The problem is less serious with inbreeding species such as wheat. Adequate precautions to avoid pollen contamination during sampling and in the lab should be taken.

The important requirement of reproducibility within the same individual is impossible to fulfil in the case of small seeds. It has been argued that, in these cases, reproducibility can be either the amplification of several targets from one sample and/or the successful analysis of other individuals from the same sample or from samples from the same layer (Allaby et al. 1997; Blatter et al. 2002a; Manen et al. 2003; Pollmann et al. 2005). With larger specimens, independent verification and reproduction of results from the same individual is possible (Liepelt et al. 2006). Other 
important points for authentication concern appropriate molecular behaviour and phylogenetic sense. These are exigencies that can be fulfilled even with small botanical remains. However, a decision based on phylogenetic sense depends on the taxonomic level, on the current knowledge of molecular diversity at a particular genetic locus, or on known ancestry.

Because of the possibility of pre-laboratory contamination, independent lab verification is useful only in certain cases, when novel or unexpected results are obtained, such as the first identification of Neanderthal sequences (Pääbo et al. 2004). Independent verification in a different laboratory and/or plausible authentication arguments have for example recently been presented by Jaenicke-Després et al. (2003), Erickson et al. (2005), Pollmann et al. (2005) and Liepelt et al. (2006). We follow the reasoning of Gilbert et al. (2005) that in every publication on aDNA, sufficient and congruent evidence must be presented to support the authentic origin of the results obtained, so that the reader can evaluate the validity of the results: “..., we advocate that readers, reviewers and authors ask "What information is presented here that makes the results and/or conclusions believable?' and "Is there any reason to not believe this?" (Gilbert et al. 2005).

\section{Preservation}

The predominant archaeological plant remains are seeds, pollen and wood; leaves are rarely found. In particular seeds and pollen, as the plant's reproductive organs, are intended for long-term DNA preservation and are often protected with a sturdy or lignified exocarp. They are thus an ideal source for DNA.

Archaeological plant remains from European sites are often retrieved from sediments by flotation with water. Exceptions are storage assemblages or large specimens collected in situ, from desert-like sites or other more exceptional excavation sites. The effects of water flotation on DNA content and preservation after recovery have not been studied so far.

At first glance, charred remains do not seem to be favourable for DNA survival. This is clearly reflected by low success rates with charred wheat remains (Brown et al. 1994, 1998; Allaby et al. 1997; Schlumbaum et al. 1998; Blatter et al. 2002a). However, these independent publications support DNA survival in a few cases, possibly because of exposure to low fire temperatures. Charring experiments suggest the preservation of DNA under conditions of low oxygen and low temperatures (below $200^{\circ} \mathrm{C}$ ), temperatures such as exist in smouldering fires or below the surface, for example in storage pits (Chalfoun and Tuross 1999; Jacomet et al. 2002; Threadgold and Brown 2003). In this case, the challenge will be to develop morphological non-destructive criteria to detect those plant remains which have undergone low enough charring temperatures for DNA survival.

Preservation of aDNA at sites with a hot and dry climate, such as in Egypt, is equally little understood and controversial. Publications on the low success rates of aDNA amplification in humans (Krings et al. 1999) or in cattle (Edwards et al. 2004), or the complete loss of authentic DNA in papyri from as recently as the 8th century AD (Marota et al. 2002), contrast with papers reporting sufficiently good DNA preservation at other but similar sites (O'Donoghue et al. 1994, 1996; Deakin et al. 1998a, b; Graver et al. 2001; Kahila Bar-Gal et al. 2002). Radish and sorghum remains from these sites are preserved through desiccation and have earlier dates than the papyri.

Similarly, preservation through waterlogging does not seem to favour DNA preservation, as hydrolysis is one of the major decay reactions. However, waterlogged plant remains with a hardy exocarp, such as grape seeds, cherry or olive fruit stones, have been shown to be a good source of ancient DNA (Manen et al. 2003; Elbaum et al. 2005; Pollmann et al. 2005).

To the best of our knowledge, amplification efficiency has not been studied comprehensively in relation to the preservation condition or type of plant remains. Thus far in plants, remains preserved by desiccation (e.g. from herbarium material), waterlogging or cold offer the best chances for DNA investigations, with similar success rates to those known from animal aDNA studies.

\section{Examples of markers used in ancient DNA studies}

In this section, we give some examples of the use of different markers in DNA studies serving different purposes. These can be either so-called universal primers, which are conserved among species and will detect more than one plant species or genome, or specific primers, often from non-coding regions and designed to amplify a single species. In aDNA studies, the size of the target is usually between 80 and $300 \mathrm{bp}$, and prior knowledge of sequence information is needed in all cases.

It is generally accepted that markers which occur in multiple copies, such as chloroplast or nuclear ribosomal markers have more chances of survival than single copy markers. For this reason, in plant studies chloroplast markers are most often chosen, although nuclear genes carry most of the agronomically important information and have higher mutation rates compared to plastid markers. 
Chloroplast DNA markers

The abundance of chloroplasts leads to the potential preservation of numerous target copies. In many plants chloroplasts are inherited maternally, but exceptions exist (e.g. Pinus species). The chloroplast genomes (cpDNA) are organised in a similar way in all plants.

Due to their low mutation rate, most chloroplast markers are phylogenetically informative at higher taxonomic levels such as orders or families (Clegg 1993; Gielly and Taberlet 1994; Savolainen and Chase 2003). However, some markers are variable enough to be of use even at species level (Pollmann et al. 2005) or, through the geographic distribution of alleles, are useful for the reconstruction of origins (Deguilloux et al. 2003; Erickson et al. 2005). As a prerequisite, chloroplast-containing tissue must be preserved (e.g. the wheat embryo).

$r b c \mathrm{~L}$

The chloroplast $r b c \mathrm{~L}$ gene codes for the large sub-unit of ribulose-1,5-bisphosphate carboxylase, an enzyme playing an important role in photosynthesis. In aDNA research, $r b c \mathrm{~L}$ was used for identification of plant orders or families from faeces (Poinar et al. 1998; Hofreiter et al. 2000, 2003; Kuch et al. 2002), gut contents (Rollo et al. 2002), and sediments (Willerslev et al. 2003), for studies on DNA preservation (Banerjee and Brown 2002; Marota et al. 2002) and for authentication purposes (Blatter et al. 2002a; Manen et al. 2003). The advantage of this locus is that sequences covering almost all plant families can be found in the public databases. The genetic identification of taxa to a higher order using $r b c \mathrm{~L}$ is rather unsatisfactory compared to morphological identification, which in most cases is to species or genus level, and interpretation of genetic results often relies on prior archaeobotanical or biogeographical knowledge. The taxonomical resolution level of $r b c \mathrm{~L}$ may be informative enough in cases such as faeces, where the producing animal is known to have had a species-poor, known diet or was living in a region with a restricted and known plant diversity.

\section{trn introns and spacers}

Non-coding chloroplast regions are more variable and thus more appropriate for use at an intraspecific level. Examples are the spacers between transfer RNA (tRNA) coding segments such as $t r n \mathrm{~L}-t r n \mathrm{~F}$ and $\operatorname{trn} \mathrm{D}-t r n \mathrm{~T}$. A segment of the $\operatorname{trn} \mathrm{L}-t r n \mathrm{~F}$ spacer was used to identify the maternal parent of closely related and morphologically ambiguous Prunus fruit stones (Pollmann et al. 2005). trnL intron variability differentiates between forest tree genera and was used to reveal authentic genetic information from waterlogged tree remains (Liepelt et al. 2006).

In higher plants, the length of the spacers ranges from about 300 to $800 \mathrm{bp}$. As a consequence, in most archaeological samples the use of universal primers such as those suggested by Taberlet et al. (1991) will not be viable, although in the case of a medieval oak sample from France a $\operatorname{trn} \mathrm{D}-\operatorname{trn} \mathrm{T}$ sequence of around $300 \mathrm{bp}$ was reported (Dumolin-Lapègue et al. 1999). In general, primers have to be designed to fit the question to be answered by aDNA analysis. Smaller species-specific targets can be designed if it is known which species are to be expected or overlapping primers can be used to analyze larger intergenic regions.

Initiated by the concept of DNA barcoding, the chloroplast P6loop within the trnL intron was tested for identification of species in processed food and from permafrost samples. Unfortunately, the resolution was found to be low, markers failing to differentiate between archaeologically relevant taxa such as Prunus species or between T. aestivum and Secale cereale (Taberlet et al. 2006).

\section{Mitochondrial DNA markers}

In the same way as chloroplasts, mitochondria occur in high copy numbers and are, with exceptions, inherited maternally. However, plant mitochondrial DNA (mtDNA) is very different from animal mtDNA; plants have less mitochondria, and their mtDNA mutates more than ten times slower than cpDNA, or 100 times slower than animal mtDNA (Soltis et al. 1992a; Wan et al. 2004). For this and other reasons, mtDNA analysis has so far rarely been employed in plant aDNA research. One of the few examples is the use of the Cox II intron to establish the presence of aDNA from grasses at the Iceman site (Rollo et al. 1995).

\section{Nuclear DNA markers}

Nuclear DNA has been used in plant aDNA research from the very first studies onwards. In principle, only two copies of a nuclear locus exist per diploid genome. Nuclear DNA carries the important economical and domestication-related traits, and is to be preferred when exploring early selection of these traits (Jaenicke-Després et al. 2003). Wheat genome-specific glutenin genes have been used fairly extensively in aDNA research, in particular to identify polyploid wheat species (Allaby et al. 1994, 1997; Brown et al. 1994, 1997, 1998; Schlumbaum et al. 1998; Allaby et al. 1999; Blatter et al. 2002a, b). 
Microsatellites, highly polymorphic single-copy loci spread throughout the genome, are a second example of nuclear DNA useful for aDNA studies. Combinations of microsatellite loci are diagnostic for many plant cultivars, and employed to trace cultivar origins. One of the problems inherent in the use of microsatellites in aDNA research is that dinucleotide repeats are most common and microsatellites are often longer than the 90-300 bp length usually amplified. They are easily amplified incorrectly due to polymerase slippage during PCR or due to degradation of the target. In such cases, cloning of several PCR products is needed to identify the correct satellite length. Eight microsatellite loci have recently been determined to be standard for cultivar identification in grapevines (This et al. 2004). Two of these, plus an additional locus, were used in a study of $V$. vinifera seeds from different European archaeological sites (Manen et al. 2003). Sequencing of the ancient amplification products yielded new sequence variants in ancient vine, that had not been detected in modern cultivars. Similarly, microsatellites have been used to study the spread of maize in South America (Lia et al. 2007).

The nuclear alcohol dehydrogenase locus $(a d h)$ is highly variable in maize due to its repeat structure and length variations. The locus was used to investigate biogeography, spread and diversity in maize (Goloubinoff et al. 1993; Freitas et al. 2003).

As more genomes are sequenced completely and more genes are identified, more genes which have been selected during domestication will be discovered and their functions characterised. It has been shown that it is possible to analyse small (approximately $90 \mathrm{bp}$ ) targets of such nuclear genes $(s u l, t b l, p b f)$ in ancient maize and to use this information to refine our understanding of domestication processes (Jaenicke-Després et al. 2003).

\section{Nuclear ribosomal DNA loci}

Finally, nuclear ribosomal DNA (rDNA) genes are of interest for aDNA research, as they contain hundreds of units of two variable spacer regions between the $18 \mathrm{~S}$, the $5.8 \mathrm{~S}$ and the $26 \mathrm{~S}$ genes, the so-called internal transcribed spacer regions 1 and 2 (ITS1 and ITS2), thus increasing the chances of DNA survival. These loci have been employed for phylogenetical analysis at the genus level in modern plants (Knaak et al. 1990; Soltis et al. 1992a; Alvarez and Wendel 2003). However, they have the disadvantage that different copies within one diploid individual or several copies within polyploids can exist (Knaak et al. 1990; Soltis et al. 1992a; Alvarez and Wendel 2003), which may result in the amplification of mosaic sequences caused by "jumping PCR". In aDNA research they have been used in sorghum (Deakin et al. 1998a, b), in wheat (Allaby et al.
1997) and in Prunus (Pollmann et al. 2005). Several methods can be used to identify species. In most aDNA cases, longer targets, with primers spanning approximately $700 \mathrm{bp}$ between $18 \mathrm{~S}$ and $26 \mathrm{~S}$, may not work, but shorter targets can be designed, for example to identify species if the family/genus of the sample is known. In this case too, overlapping primers may be useful.

\section{Concluding remarks}

For some plant biologists, the publications about DNA from Miocene Magnolia leaves and similar papers (Golenberg et al. 1990; Soltis et al. 1992b; Poinar et al. 1993) sparked off the interest in plant aDNA. It was a lesson on rapid evolution in scientific research. First came the exciting possibility of using palaeontological and archaeological plants directly to understand evolution and phylogeny without having to use mathematical models. Later came the realisation that the PCR method, although easy to use, had more drawbacks than initially thought (Austin et al. 1997; Sykes 1997; Austin et al. 1998).

Although limitations still exist, we have shown here that the analysis of plant aDNA has since then evolved into a useful tool for investigating and answering archaeologically and archaeobotanically relevant questions. These include questions such as species identification, origin and spread of cultivated plants or monitoring the state of domestication-questions that cannot be answered by morphological archaeobotanical studies alone.

Today the future of aDNA research looks varied; it can continue to help understand preservation of DNA in different types of plant material, such as material from stalks, glumes, leaves, lignified fruits or from wood, where initial attempts have been made. New technologies such as realtime PCR, or new sequencing techniques such as pyrosequencing will also impact the field of ancient plant genetics, similarly to aDNA research in animals. With the availability of present-day sequences of agronomically important genes and of geographically structured loci, and with the further refining of aDNA methodology, archaeological plant remains can become a key to the understanding of genetic processes linked to human impact. Last but not least, understanding the conditions leading to DNA preservation in plants may help to develop strategies for conservation of DNA in plant DNA banks, to best preserve our heritage (Savolainen and Reeves 2004; Hodkinson et al. 2007).

Acknowledgments AS wishes to thank her colleagues Meral Turgay and Britta Pollmann for wonderful support and, together with Robert Blatter, for critical comments on the manuscript. We thank two anonymous reviewers for valuable comments and suggestions to improve the text. 


\section{References}

Allaby RG, Jones MK, Brown TA (1994) DNA in charred wheat grains from the Iron Age hillford at Danebury, England. Antiquity 68:126-132

Allaby RG, O’Donoghue K, Sallares R, Jones MK, Brown TA (1997) Evidence for the survival of ancient DNA in charred wheat seeds from European archaeological sites. Anc Biomol 1:119-129

Allaby RG, Banerjee M, Brown TA (1999) Evolution of the highmolecular-weight glutenin loci of the A, B, D and G genomes of wheat. Genome 42:296-307

Alvarez I, Wendel JF (2003) Ribosomal ITS sequences and plant phylogeny inference. Mol Phylogenet Evol 29:417-434

Aradhya MK, Dangl GS, Prins BH, Boursiquot JM, Walker MA, Meredith CP, Simon C (2003) Genetic structure and differentiation in cultivated grape, Vitis vinifera L. Genet Res Cambridge 81:179-192

Arroyo-Garcia R, Ruiz-Garcia L, Bolling R, Ocete R, Lopez MA, Arnolds C, Ergul A, Söylemezoglu G, Uzun HI, Cabello F, Ibanez J, Aradhya MK, Atanassov A, Atanassov I, Balint S, Cenis JL, Costantini L, Goris-Lavets S, Grando MS, Klein BY, McGovern PE, Merdinoglu D, Pejic I, Pelsy F, Primikirios N, Risovannaya V, Roubelakis-Angelakis KA, Snoussi H, Sotiri P, Tamhankar S, This P, Troshin L, Malpica JM, Lefort F, Martinez-Zapater JM (2006) Multiple origins of cultivated grapevine (Vitis vinifera L. ssp. sativa) based on chloroplast DNA polymorphisms. Mol Ecol 15:3707-3714

Austin JJ, Ross AJ, Smith AB, Fortey RA, Thomas RH (1997) Problems of reproducibility-does geologically ancient DNA survive in amber-preserved insects. Proc R Soc Lond B 264:467-474

Austin JJ, Smith AB, Fortey RA, Thomas RH (1998) Ancient DNA from amber inclusions: a review of the evidence. Anc Biomol 2:167-176

Banerjee M, Brown TA (2002) Preservation of nuclear but not chloroplast DNA in archaeological assemblages of charred wheat grains. Anc Biomol 4:59-64

Bennett KD, Parducci L (2006) DNA from pollen: principles and potential. The Holocene 16:1031-1934

Benz BF (2001) Archaeological evidence of teosinte domestication from Guila Naquitz, Oaxaca. Proc Nat Acad Sci USA 98:21042106

Blatter R, Jacomet S, Schlumbaum A (2002a) Little evidence for the presence of single copy genes in charred archaeological wheat. Anc Biomol 4:65-78

Blatter R, Jacomet S, Schlumbaum A (2002b) Spelt-specific alleles in HMW glutenin genes from modern and historical European spelt (Triticum spelta L.). Theor Appl Genet 104:329-337

Bower MA, Spencer M, Matsamura S, Nisbet RER, Howe CJ (2005) How many clones need to be sequenced from a single forensic or ancient DNA sample in order to determine a reliable consensus sequence? Nucleic Acids Res 33:2549-2556

Brown TA (1999) How ancient DNA may help in understanding the origin and spread of agriculture. Phil Trans R Soc Lond B 354:89-98

Brown TA, Brown KA (1994) Ancient DNA: using molecular biology to explore the past. BioEssays 16:719-726

Brown TA, Allaby RG, Brown KA, Jones MK (1993) Biomolecular archaeology of wheat: past, present and future. World Archaeol 25:64-73

Brown TA, Allaby RG, Brown KA, ÓDonoghue K, Sallares R (1994) DNA in wheat seeds from European archaeological sites. Experientia 50:571-575

Brown TA, Allaby RG, Sallares R, Jones G (1998) Ancient DNA in charred wheats: taxonomic identification of mixed and single grains. Anc Biomol 2:185-193
Bruns TD, Fogel R, Taylor JW (1990) Amplification and sequencing of DNA from fungal herbarium specimens. Mycologia 82:175184

Burger J, Hummel S, Herrmann B, Henke W (1999) DNA preservation: a microsatellite-DNA study on ancient sceletal remains. Electrophoresis 20:1722-1728

Chalfoun DJ, Tuross N (1999) Botanical remains: utility in protein and DNA research. Anc Biomol 3:67-79

Clegg MT (1993) Chloroplast gene sequences and the study of plant evolution. Proc Natl Acad Sci USA 90:363-367

Cooper A, Poinar HN (2000) Ancient DNA: do it right or not at all. Science 289:1139

Deakin WJ, Rowley-Conwy P, Shaw CH (1998a) Amplification and sequencing of DNA from preserved sorghum of up to 2800 years antiquity found at Qasr Ibrim. Anc Biomol 2:27-41

Deakin WJ, Rowley-Conwy P, Shaw CH (1998b) The sorghum of Qasr Ibrim: reconstructing DNA templates from ancient seeds. Anc Biomol 2:117-124

Deguilloux MF, Pemonge H, Bertel L, Kremer A, Petit RJ (2003) Checking the geographical origin of oak wood: molecular and statistical tools. Mol Ecol 12:1629-1636

Doebley J (2004) The genetics of maize evolution. Annu Rev Genet 38:37-59

Dumolin-Lapègue S, Pemonge MH, Gielly L, Taberlet P, Petit RJ (1999) Amplification of oak DNA from ancient and modern wood. Mol Ecol 8:2137-2140

Edwards CJ, MacHugh DE, Dobney KM, Martin L, Russell N, Horwitz LK, McIntosh SK, MacDonald KC, Helmer D, Tresset A, Vigne JD, Bradley DG (2004) Ancient DNA analysis of 101 cattle remains: limits and prospects. J Archaeol Sci 31:695-710

Elbaum R, Melamed-Bessudo C, Boaretto E, Galili E, Lev-Yadun S, Levy AA, Weiner S (2005) Ancient olive DNA in pits: preservation, amplification and sequence analysis. J Archaeol Sci 33(1):77-88

Erickson DL, Smith BD, Clarke AC, Sandweiss DH, Tuross N (2005) An Asian origin for a 10,000-year-old domesticated plant in the Americas. Proc Nat Acad Sci USA 102:18315-18320

Freitas FO, Bendel G, Allaby RG, Brown TA (2003) DNA from primitive maize landraces and archaeological remains: implications for the domestication of maize and its expansion into South America. J Archaeol Sci 30:901-908

Gielly L, Taberlet P (1994) The use of chloroplast DNA to resolve plant phylogenies: noncoding versus $r b c L$ sequences. Mol Biol Evol 11:769-777

Gilbert MTP, Willerslev E, Hansen AJ, Barnes I, Rudbeck L, Lynnerup N, Cooper A (2003) Distribution patterns of postmortem damage in human mitochondrial DNA. Am J Human Genet 72:32-47

Gilbert MTP, Bandelt HJ, Hofreiter M, Barnes I (2005) Assessing ancient DNA studies. Trends Ecol Evol 20:541-544

Gilbert MTP, Binladen J, Miller W, Wiuf C, Willerslev E, Poinar H, Carlson JE, Leebens-Mack JH, Schuster SC (2007a) Recharacterization of ancient DNA miscoding lesions: insights in the era of sequencing-by-synthesis. Nucleic Acids Res 35:1-10

Gilbert MTP, Moore W, Melchior L, Worobey M (2007b) DNA extraction from dry museum beetles without conferring external morphological damage. PloS ONE 3:e272

Golenberg EM, Giannasi DE, Clegg MT, Smiley CJ, Durbin M, Henderson D, Zurawski G (1990) Chloroplast DNA sequence from a Miocene Magnolia species. Nature 344:656-658

Goloubinoff P, Pääbo S, Wilson AC (1993) Evolution of maize inferred from sequence diversity of an Adh2 gene segment from archaeological specimens. Proc Natl Acad Sci USA 90:19972001 
Graver AM, El Molto J, Parr RL, Walters S, Praymak RC, Maki JM (2001) Mitochondrial DNA research in the Dakhleh Oasis, Egypt: a preliminary report. Anc Biomol 3:239-253

Gugerli F, Parducci L, Petit RJ (2005) Ancient plant DNA: review and prospects. New Phytol 166:409-418

Gyulai G, Humphreys M, Lagler R, Szabo Z, Toth Z, Bittsansky A, Gyulai F, Heszky L (2006) Seed remains of common millet from the 4th (Mongolia) and 15th (Hungary) centuries: AFLP, SSR and mtDNA sequence recoveries. Seed Sci Res 16:179191

Haile J, Holdaway R, Oliver K, Bunce M, Gilbert MTP, Nielsen R, Munch K, Ho SYW, Shapiro B, Willerslev E (2007) Ancient DNA chronology within sediment deposits: are paleobiological reconstructions possible and is DNA leaching a factor? Mol Biol Evol 24:982-989

Hansen AJ, Mitchell DL, Wiuf C, Paniker L, Brand TB, Binladen J, Gilichinsky DA, Rønn R, Willerslev E (2006) Crosslinks rather than strand breaks determine access to ancient DNA sequences. Genetics 173:1175-1179

Ho SYW, Heupink TH, Rambaut A, Shapiro B (2007) Bayesian estimation of sequence damage in ancient DNA. Mol Biol Evol 24(6):1416-1422

Hodkinson TR, Waldren S, Parnell JAN, Kelleher CT, Salamin K, Salamin N (2007) DNA banking for plant breeding, biotechnology and biodiversity evaluation. J Plant Res 120:17-29

Hofreiter M, Poinar HN, Spaulding WG, Bauer K, Martin PS, Possnert G, Pääbo S (2000) A molecular analysis of ground sloth diet through the last glaciation. Mol Ecol 9:1975-1984

Hofreiter M, Betancourt JL, Sbriller AP, Markgraf V, McDonald HG (2003) Phylogeny, diet, and habitat of an extinct ground sloth from Cuchillo Cura, Neuquén Province, southwest Argentina. Q Res 59:364-378

Hummel S (2003) Ancient DNA: recovery and analysis. Encyclopedia of the Human Genome, 342

Iniguez AM, Araujo A, Ferreira LF, Vicente ACP (2003) Analysis of ancient DNA from coprolites: a perspective with random amplified polymorphic DNA-polymerase chain reaction approach. Mem Inst Oswaldo Cruz 98:63-65

Jacomet S, Kreuz A (1999) Lehrbuch der Archäobotanik. Ulmer, Stuttgart

Jacomet S, Mermod O (2002) Der Gutshof als wirtschaftliche Produktionseinheit. In: Flutsch L, Niffeler U, Rossi F (eds) Die Römerzeit in der Schweiz. Schweizerische Gesellschaft für Ur- und Frühgeschichte, Basel, pp 155-164

Jacomet S, Schlichtherle H (1984) Der kleine Pfahlbauweizen Oswald Heer's-Neue Untersuchungen zur Morphologie neolithischer Nacktweizen-Ähren. In: van Zeist W, Casparie WA (eds) Plants and ancient man: studies in palaeoethnobotany. A. A. Balkeema, Rotterdam, pp 153-176

Jacomet S, Brombacher C, Dick M (1989) Archäobotanik am Zürichsee. Orell Füssli, Zürich

Jacomet S, Kucan D, Ritter A, Suter G, Hagendorn A (2002) Punica granatum L. (pomegranates) from early Roman contexts in Vindonissa (Switzerland). Veget Hist Archaeobot 11:79-92

Jaenicke-Després V, Buckler ES, Smith BD, Gilbert MTP, Cooper A, Doebley J, Pääbo S (2003) Early allelic selection in maize as revealed by ancient DNA. Science 302:1206-1208

Jones M, Brown TA (2000) Agricultural origins: the evidence of modern and ancient DNA. The Holocene 10:769-776

Jones M, Brown T, Allaby R (1996) Tracking early crops and early farmers: the potential of biomolecular archaeology. In: Harris DR (ed) The origins and spread of agriculture and pastoralism in Eurasia. University College, London, pp 94-100

Jones G, Valamoti S, Charles M (2000) Early crop diversity: a "new" glume wheat from northern Greece. Veget Hist Archaeobot 9:133-146
Kahila Bar-Gal G, Khalaily H, Mader O, Ducos P, Kolska Horwitz L (2002) Ancient DNA evidence for the transition from wild to domestic status in Neolithic goats: a case study from the site of Abu Gosh, Israel. Anc Biomol 4:9-17

Knaak C, Hamby RK, Arnold ML, Leblanc MD, Chapman RL, Zimmer EA (1990) Ribosomal DNA variation and its use in plant biosystematics. In: Kawano S (ed) Biological approaches and evolutionary trends in plants. Academic, London, pp 135158

Kohler-Schneider M (2003) Contents of a storage pit from late Bronze Age Stillfried, Austria: another record of the "new" glume wheat. Veget Hist Archaeobot 12:105-111

Krings M, Halim Salem A, Bauer K, Geisert H, Malek AK, Chaix L, Simon C, Welsby D, Di Rienzo A, Utermann G, Sajantila A, Pääbo S, Stoneking M (1999) mtDNA analysis of Nile River Valley populations: a genetic corridor or a barrier to migration. Am J Hum Genet 64:1166-1176

Kuch M, Rohland N, Betancourt JL, Latorre C, Steppans S, Poinar HN (2002) Molecular analysis of a 11700 -year-old rodent midden from the Atacama Desert, Chile. Mol Ecol 11:913-924

Lia VV, Confalonieri VA, Ratto N, Cámara Hernández JA, Miante Alzogaray AM, Poggio L, Brown TA (2007) Microsatellite typing of ancient maize: insights into the history of agriculture in southern South America. Proc R Soc Lond B 274:545-554

Liepelt S, Sperisen C, Deguilloux MF, Petit RJ, Kissling R, Spencer M, de Beaulieu JL, Taberlet P, Gielly L, Ziegenhagen B (2006) Authenticated DNA from ancient wood remains. Ann Bot 98:1107-1111

Luo MC, Yang ZL, You FM, Kawahara T, Waines JG, Dvorak J (2007) The structure of wild and domesticated emmer wheat populations, gene flow between them, and the site of emmer domestication. Theor Appl Genet 114:947-959

Maier U (1996) Morphological studies of free-threshing wheat ears from a Neolithic site in southwest Germany, and the history of the naked wheats. Veget Hist Archaeobot 5:39-55

Manen JF, Bouby L, Dalnoki O, Marinval P, Turgay M, Schlumbaum A (2003) Microsatellites from archaeological Vitis vinifera seeds allow a tentative assignment of the geographical origin of ancient cultivars. J Archaeol Sci 30:721-729

Margulies M, Egholm M, Altman WE, Attiya S, Bader JS, Bemben LA, Berka J et al (2005) Genome sequencing in microfabricated high-density picolitre reactors. Nature 437:376-380

Marota I, Basile C, Ubaldi M, Rollo F (2002) DNA decay rate in papyri and human remains from Egyptian archaeological sites. Am J Phys Anthropol 117:310-318

Morrel PL, Clegg MT (2007) Genetic evidence for a second domestication of barley (Hordeum vulgare) east of the fertile crescent. Proc Natl Acad Sci USA 104:3289-3294

O’Donoghue K, Brown TA, Carter JF, Evershed RP (1994) Detection of nucleotide bases in ancient seeds using gas chromatography/ mass spectrometry and gas chromatography/mass spectrometry/ mass spectrometry. Mass Spectrom 8:503-508

O'Donoghue K, Clapham A, Evershed RP, Brown TA (1996) Remarkable preservation of biomolecules in ancient radish seeds. Proc R Soc Lond Ser B Biol Sci 263:541-547

Pääbo S, Irwin DM, Wilson AC (1990) DNA damage promotes jumping between templates during enzymatic amplification. J Biol Chem 265:4718-4721

Pääbo S, Poinar H, Serre D, Jaenicke-Després V, Hebler J, Rohland N, Kuch M, Krause J, Vigilant L, Hofreiter M (2004) Genetic analyses from ancient DNA. Annu Rev Genet 38:645-679

Parducci L, Petit RJ (2004) Ancient DNA- unlocking plants' fossil secrets. New Phytol 161:335-339

Parducci L, Suyama Y, Lascoux M, Bennett KD (2005) Ancient DNA from pollen: a genetic record of population history of Scots pine. Mol Ecol 14:2873-2882 
Payne PI (1987) Genetics of wheat storage proteins and the effect of allelic variation on bread-making quality. Ann Rev Plant Physiol Plant Mol Biol 38:141-153

Piperno DR, Flannery KV (2001) The earliest archaeological maize (Zea mays L.) from highland Mexico: new accelerator mass spectrometry dates and their implications. Proc Nat Acad Sci USA 98:2101-2103

Poinar HN (2002) The genetic secrets some fossils hold. Acc Chem Res 35:676-684

Poinar HN, Cano RJ, Poinar GO (1993) DNA from an extinct plant. Nature 363:677

Poinar HN, Hofreiter M, Spaulding WG, Martin PS, Stankiewicz BA, Bland H, Evershed RP, Possnert G, Pääbo S (1998) Molecular coproscopy: dung and diet of the extinct ground sloth Nothrotheriops shastensis. Science 281:402-406

Poinar HP, Kuch M, Sobolik KD, Barnes I, Stankiewicz AB, Kuder T, Spaulding WG, Bryant VM, Cooper A, Pääbo S (2001) A molecular analysis of dietary diversity for three archaic Native Americans. Proc Natl Acad Sci USA 98:4317-4322

Pollmann B, Jacomet S, Schlumbaum A (2005) Morphological and genetic studies of waterlogged Prunus species from the Roman vicus Tasgetium, Switzerland. J Archaeol Sci 32: $1471-1480$

Pruvost M, Schwarz R, Bessa Correira V, Champlot S, Braguier S, Morel N, Fernandez-Jalvo Y, Grange T, Geigl EM (2007) Freshly excavated fossil bones are best for amplification of ancient DNA. Proc Natl Acad Sci USA 104:739-744

Ristaino JB (2002) Tracking historic migrations of the Irish potato famine pathogen, Phytophthora infestans. Microbes Infect 4:1369-1377

Ristaino JB, Groves CT, Parra GR (2001) PCR amplification of the Irish potato famine pathogen from historic specimens. Nature 411:695-697

Rogers SO (1994) Phylogenetic and taxonomic information from herbarium and mummified DNA. In: Adams RP, Miller JS, Golenberg EM, Adams JE (eds) Conservation of plant genes II: utilization of ancient and modern DNA. Missouri Botanical Garden, Missouri, pp 47-67

Rogers SO, Bendich AJ (1985) Extraction of milligram amounts of fresh, herbarium, and mummified plant tissues. Plant Mol Biol 5:69-76

Rohland N, Hofreiter M (2007) Comparison and optimization of ancient DNA extraction. BioTechniques 42:343-352

Rollo F, Asci W, Sassaroli S (1994) Assessing the genetic variation in pre-Columbian maize at the molecular level. In: Adams RP, Miller JS, Golenberg EM, Adams JE (eds) Conservation of plant genes II: utilization of ancient and modern DNA. Missouri Botanical Garden, Missouri, pp 27-35

Rollo F, Asci W, Marota I, Sassaroli S (1995) DNA analysis of grass remains found at the Iceman's archaeological site. In: Spindler K (ed) Der Mann im Eis. Springer, Wien, p 320

Rollo F, Ubaldi M, Ermini L, Marota I (2002) Ötzi's last meals: DNA analysis of the intestinal content of the Neolithic glacier mummy from the Alps. Proc Natl Acad Sci USA 99:12594-12599

Ronaghi M (2001) Pyrosequencing sheds light on DNA sequencing. Genome Res 11:3-11

Savolainen V, Chase MW (2003) A decade of progress in plant molecular phylogenetics. Trends Genet 19:717-724

Savolainen V, Reeves G (2004) A plea for DNA banking. Science 304:1445

Savolainen V, Cuénoud P, Spichiger R, Martinez MDP, Crèvecoeur M, Manen JF (1995) The use of herbarium specimens in DNA phylogenetics: evaluation and improvement. Plant Syst Evol 197:87-98

Schlumbaum A, Neuhaus JM, Jacomet S (1998) Coexistence of tetraploid and hexaploid naked wheat in a Neolithic lake dwelling of Central Europe. Evidence from morphology and ancient DNA. J Archaeol Sci 25:1111-1118

Sefc KM, Lopes MS, Lefort F, Botta R, Roubelakis-Angelakis kA, Ibanez J, Pejic I, Wagner HW, Glössl J, Steinkeller H (2000) Microsatellite variability in grapevine cultivars from different European regions and evaluation of assignment testing to assess the geographic origin of cultivars. Theor Appl Genet 100:498505

Siles BA, O’Neil KA, Fox MA, Anderson DE, Kuntz AF, Ranganath SC, Morris AC (2000) Genetic fingerprinting of grape plant (Vitis vinifera) using random amplified polymorphic DNA (RAPD) analysis and dynamic size-sieving capillary electrophoresis. J Agric Food Chem 48:5903-5912

Smith CI, Chamberlain AT, Riley MS, Cooper A, Stringer CB, Collins MJ, Linder CR, Moore LA, Jackson RB (2001) Neanderthal DNA. Not just old but old and cold? Nature 410:771-772

Soltis PS, Soltis DE, Doyle JJ (1992a) Molecular systematics of plants. Chapman and Hall, New York, p 434

Soltis PS, Soltis DE, Smiley CJ (1992b) An rbcL sequence from a Miocene Taxodium (bald cypress). Proc Natl Acad Sci USA 89:449-451

Stiller M, Green RE, Ronan M, Simons JF, Du L, He W, Egholm M, Rothberg JM, Keates SG, Ovodov ND, Antipina EE, Baryshnikov GF, Kuzmin YV, Vasilevski AA, Wuenschell GE, Termini J, Hofreiter M, Jaenicke-Després V, Pääbo S (2006) Pattern of nucleotide misincorporations during enzymatic amplification and direct large-scale sequencing of ancient DNA. Proc Natl Acad Sci USA 103:13578-13584

Suh HS, Cho JH, Lee YJ, Heu MH (2000) RAPD Variation of 13,010 And 17,310 Year-Old carbonized rice 4th international rice genetics symposium, Manilla, Philipines

Suyama Y, Parducci L, Lascoux M, Bennett KD (2003) Isolation of DNA from subfossil pollen. In: Petit RJ (ed) Introducing genetic and palaeogenetic approaches in plant palaeoecology and archaeology, p 22

Sykes B (1997) Lights turning red on amber. Nature 386:764-765

Taberlet P, Gielly L, Pautou G, Bouvet J (1991) Universal primers for amplification of three non-coding regions of chloroplast DNA. Plant Mol Biol 17:1105-1109

Taberlet P, Coissac E, Pompanon F, Gielly L, Miquel C, Valentini A, Vermat T, Corthier G, Brochmann C, Willerslev E (2006) Power and limitations of the chloroplast $\operatorname{trn} \mathrm{L}$ (UAA) intron fro plant DNA barcoding. Nucleic Acids Res 35:e14

Tani N, Tsumura Y, Sato H (2003) Nuclear gene sequences and DNA variation of Cryptomeria japonica samples from the postglacial period. Mol Ecol 12:859-868

Taylor JW, Swann EC (1994) DNA from herbarium specimens. In: Herrmann B, Hummel S (eds) Ancient DNA. Springer, Heidelberg, pp 166-181

This P, Boccacci P, Borrego J, Botta RLC, Crespan M, Dangl GS, Eisenheld C, Ferreira-Monteiro F, Grando S, Ibanez J, Lacombe T, Laucou V, Magalhaes R, Meredith CP, Milani N, Peterlunger E, Regner F, Zulini L, Maul E (2004) Development of a standard set of microsatellite reference alleles for identification of grape cultivars. Theor Appl Genet 109:1448-1458

Threadgold J, Brown TA (2003) Degradation of DNA in artificially charred wheat seeds. J Archaeol Sci 30:1067-1076

Vigouroux Y, McMullen M, Hittinger CT, Houchins K, Schulz L, Kresovich S, Matsuoka Y, Doebley J (2002) Identifying genes of agronomic importance in maize by screening microsatellites for evidence of selection during domestication. Proc Natl Acad Sci USA 99:9650-9655

Vouillamoz JF, Schneider A, Grando MS (2006) Microsatellite analysis of Alpine grape cultivars (Vitis vinifera L.): alleged descendants of Pliny the Elder's Raetica are genetically 
related. Genetic Resour Crop Evolut 54(5):1095-1104 doi:10.1007/s10722-006-9001-z

Wan QH, Wu H, Fujihara T, Fang SG (2004) Which genetic marker for which conservation genetics issue. Electrophoresis 25:21652176

Wang H, Nussbaum-Wagler T, Li B, Zhao Q, Vigouroux Y, Faller M, Bomblies K, Lukens L, Doebley J (2005) The origin of the naked grains of maize. Nature 436:714-719

Wang RL, Stec A, Hey J, Lukens L, Doebley J (1999) The limits of selection during maize domestication. Nature 398: 236-239

Whitt SR, Wilson LM, Tenaillon MI, Gaut BS, Buckler EST (2002) Genetic diversity and selection in maize starch pathway. Proc Natl Acad Sci USA 99:12959-12962
Willerslev E, Hansen AJ, Binladen J, Brand TB, Gilbert MTP, Shapiro B, Bunce M, Wiuf C, Gilichinsky DA, Cooper A (2003) Diverse plant and animal genetic records from Holocene and Pleistocene sediments. Science 300:791-795

Yang DY, Watt K (2005) Contamination controls when preparing archaeological remains for ancient DNA analysis. J Archaeol Sci $32: 331-336$

Zeder MA (2006) Central questions in the domestication of plants and animals. Evol Anthropol 15:105-117

Zeder MA, Emshwiller E, Smith BD, Bradley DG (2006) Documenting domestication: the intersection of genetics and archaeology. Trends Genet 22:139-155

Zohary D, Hopf M (2000) Domestication of Plants in the old world. Clarendon Press, Oxford 